$\mathrm{Oz}$

$1-1-2018$

\title{
An Interview with Fuensanta Nieto
}

Fuensanta Nieto

Nieto Sobejano Arquitectos

Follow this and additional works at: https://newprairiepress.org/oz

Part of the Architecture Commons

(c) (i) $(9)$

This work is licensed under a Creative Commons Attribution-Noncommercial-No Derivative Works 4.0 License.

\section{Recommended Citation}

Nieto, Fuensanta (2018) "An Interview with Fuensanta Nieto," Oz: Vol. 40. https://doi.org/10.4148/ 2378-5853.1579

This Article is brought to you for free and open access by New Prairie Press. It has been accepted for inclusion in Oz by an authorized administrator of New Prairie Press. For more information, please contact cads@k-state.edu. 
An Interview with Fuensanta Nieto

\author{
Fuensanta Nieto \\ Nieto Sobejano Arquitectos
}

Describe the vision or mission of your work; what are you trying to accomplish through your architecture?

Vision and mission are two different concepts. The first expresses in my opinion a personal interpretation while the second reflects a collective objective. The vision of our architecture resides in the strength of the ideas, the close relationship with a place, the search for natural light, the creation of a complex space as a combinatory of a limited number of simple elements. The mission of our work, on the other hand, reflects not only my personal interpretation, but also affects the users as well as the city or the landscape. It contains two scales: one private and one public. On the scale of the private space I see our mission as the goal of provoking emotions and sensations, building appropiate atmospheres for the actions that determine our life: working, inhabiting, relaxing, learning, etc. In the urban scale, nevertheless, architecture should respond to a context, trying to achieve a balance between innovation and the memory of what already exists: every project has for us an essential link with memory.

What motivates you to prioritize this vision; why have you chosen to work towards this mission?

We are motivated to translate the needs of the people through architecture, but those needs are not only functional, they are also sensorial, psychic, they are made of light, material, texture, space. In other words,

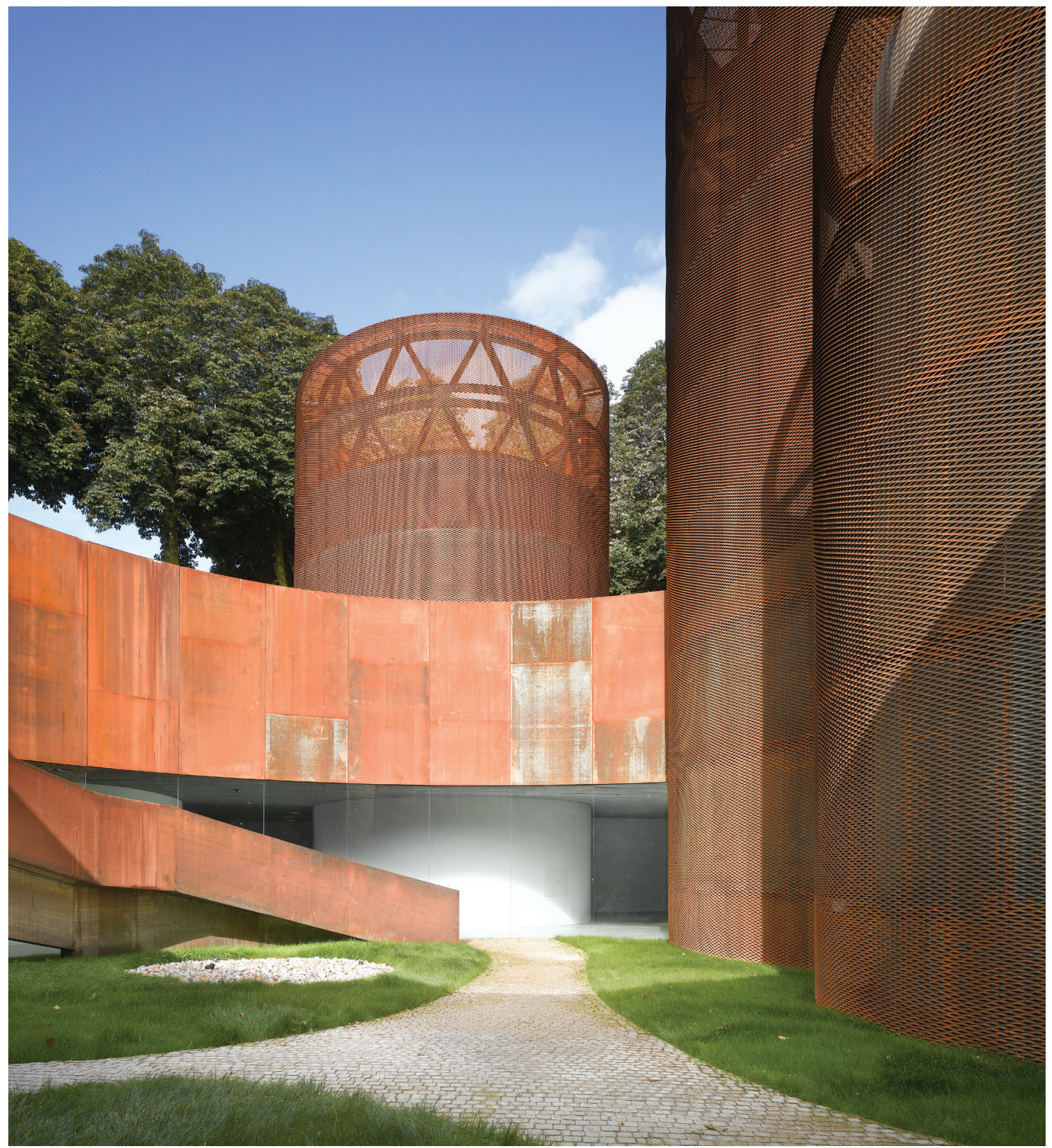



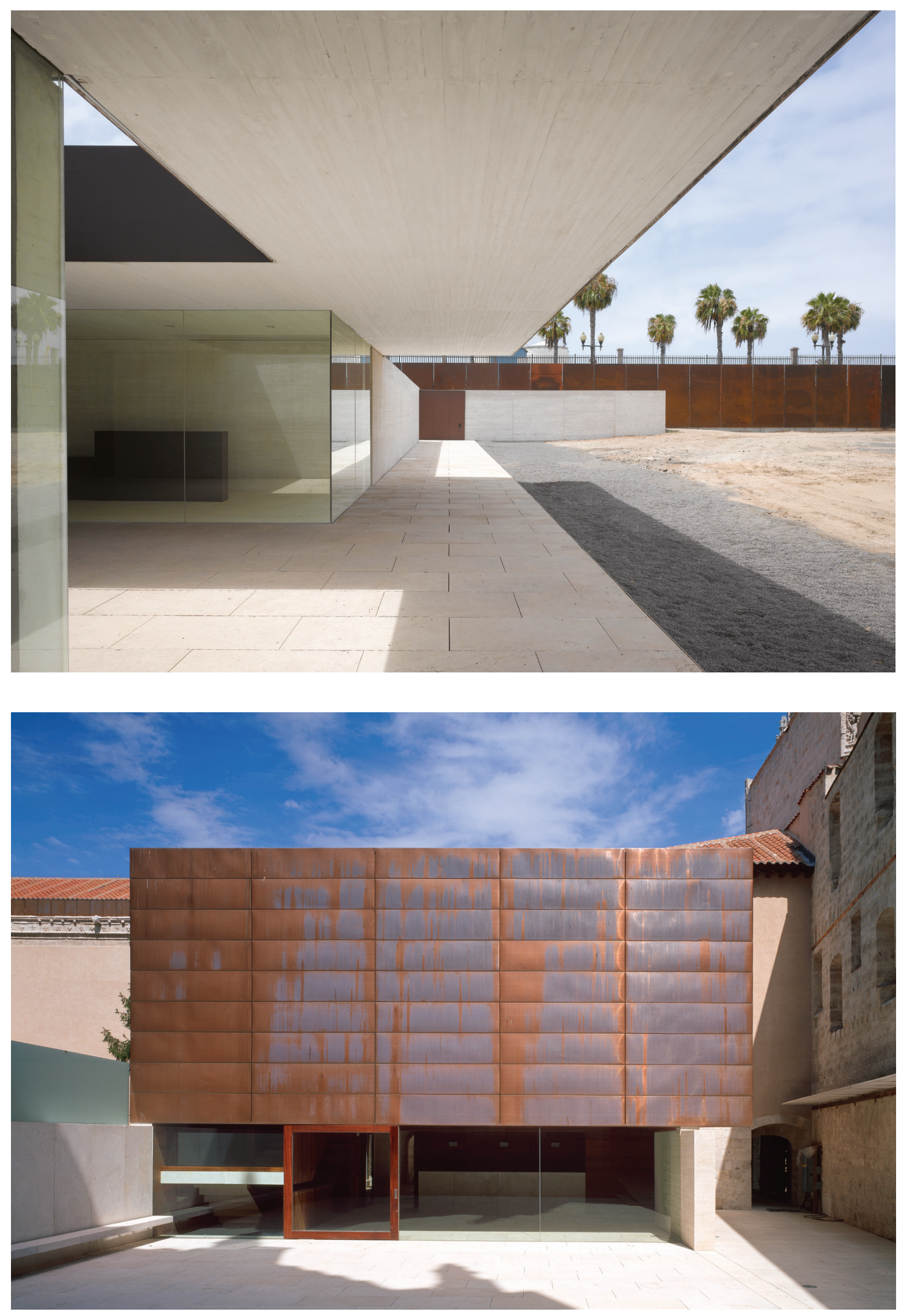

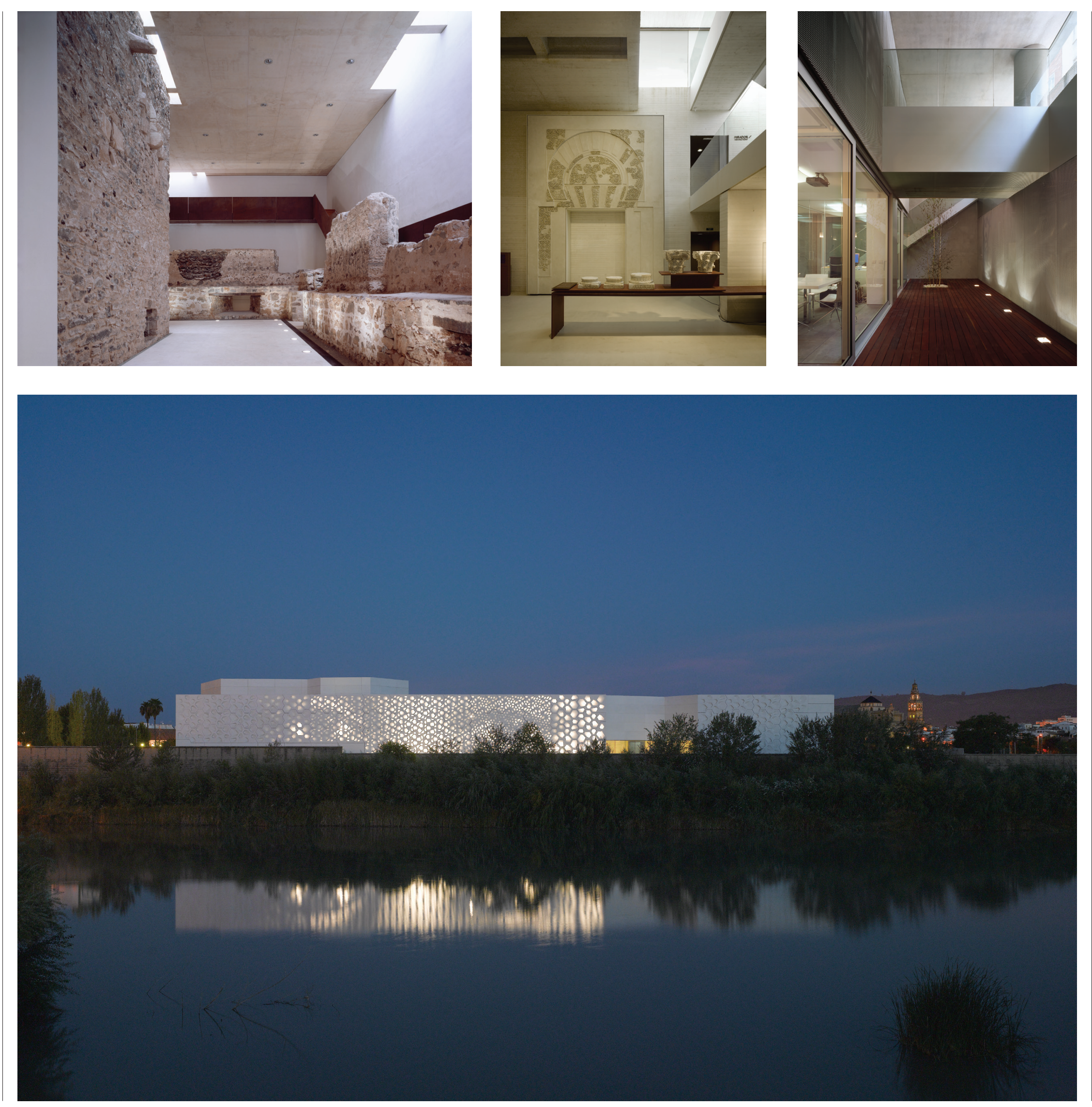


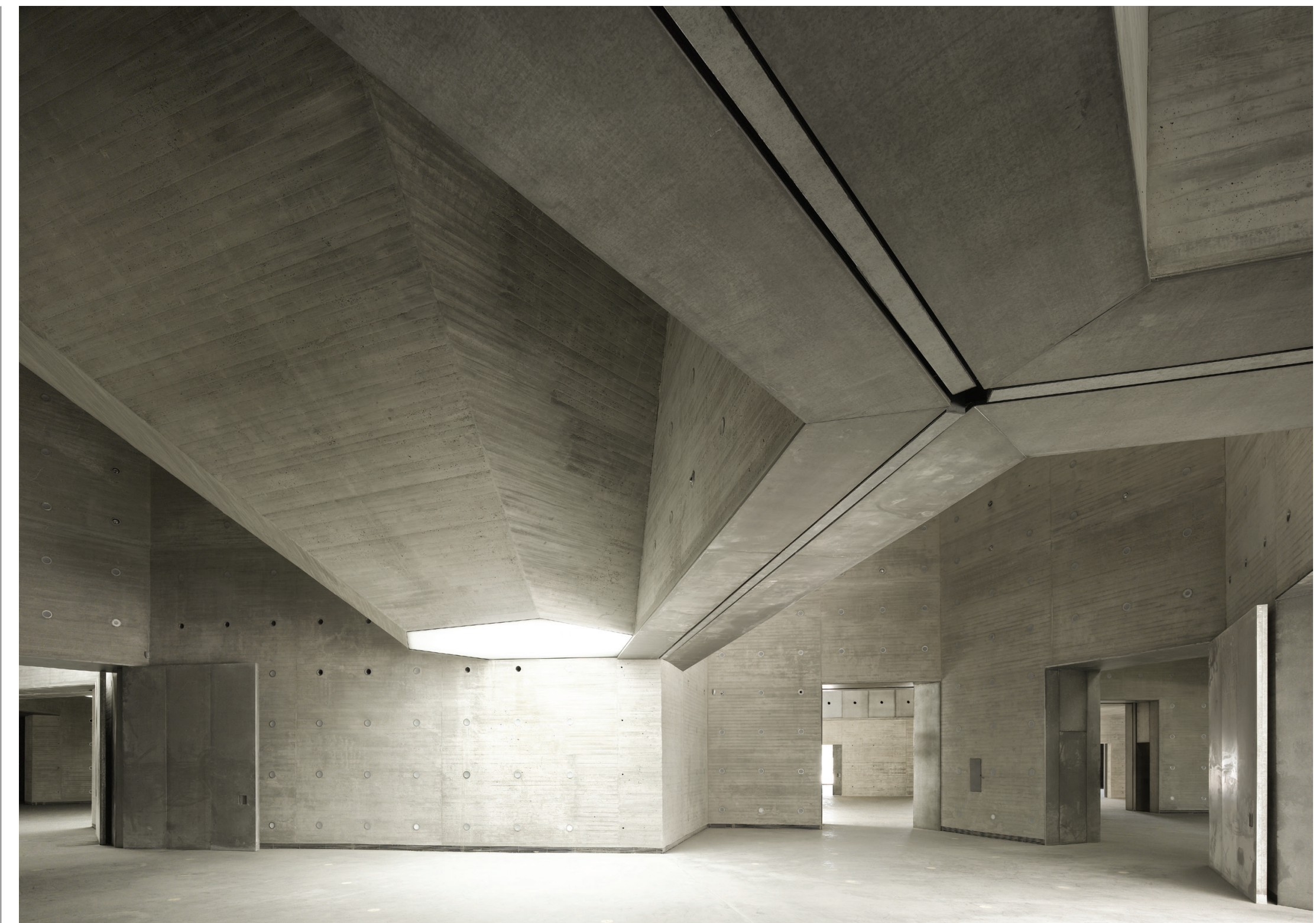

while people are usually aware of the importance of the places they live in, they need architecture to make it possible. Unfortunately, most of the constructions that are carried out everywhere tend to be banal, repetitive and do not meet the expected conditions. I would say that we feel responsible for the essential role of space in the quality of human well-being.
How do you go about creating architecture that explores this mission; how do you continuously embody this mission into what you produce?

Our interest lies in creating architecture through ideas that are transformed into projects conceived independently, at different times. They are the result of varying conditions, places, and programs but in the end they reveal multiple connections between them. In that sense each project is the mirror of another : everything we produce becomes part of this common vision.
Image Credits:

Roland Halbe Fotografie

(c) Roland Halbe 